\title{
Türkiye'de Kentsel Dönüşümün Anlamı, Aktörleri ve Amaçları
}

\author{
Uğur Sadioğlu1 \\ ORCID: 0000-0002-2454-4163
}

\author{
Eser Ergönül ${ }^{2}$ \\ ORCID: 0000-0002-3883-4129
}

Öz

Türkiye'de 2000'li yıllarda belediyeleri doğrudan ve dolaylı olarak ilgilendiren önemli yasal düzenlemeler yapılmıştır. Bazı kanunlar özel olarak belirli bir büyükşehir alanına ilişkin düzenlenmişken, Belediye Kanunu ve Büyükşehir Belediyesi Kanunu genel olarak belediyelerin kentsel dönüşüm uygulamalarını düzenlemiştir. Son olarak 2012 tarih ve 6306 sayıl Afet Riski Altındaki Alanların Dönüştürülmesi Hakkında Kanun; merkezi yönetim, Çevre ve Şehircilik Bakanlığı ve TOKİ üzerinden çeşitli düzenlemeler yapmıştır. Bu düzenlemelerle bizzat ilgili Bakanlık, TOKİ ve belediyelere hem mali kaynak hem de yetki ve görev verilmesi yoluna gidilmiştir. Böylece kentsel dönüşüm konusunda ilçe belediyeleri, büyükşehir belediyeleri, bakanlık ve idareler gibi çok sayıda aktör önemli projeleri yürütmeye çalışmaktadır. Üzerinde durulan bu kapsamlı ve çok boyutlu politika alanında en büyük rolün Bakanlı̆̆a, devamında büyükşehir belediyelerine ve son olarak ilçe belediyelerine verildiği görülmektedir.

Çalışmada kentsel dönüşümün bu çok aktörlü ve karmaşık yapısını düzenleyen mevzuat incelenmiştir. Halk nezdinde son yıllarda olumsuz bir imaj kazanan kentsel dönüşüm uygulamalarının sağlıklı bir şekilde değerlendirilmesi amaçlanarak Türkiye'deki kurumsal çerçeve analiz edilerek yorumlanmıştır.

Anahtar Kelimeler: Kentsel Dönüşüm, 6306 sayıl Kanun, kentsel dönüşüm mevzuatı, kentsel dönüşüm kurumları.

${ }^{1}$ Doç. Dr., Hacettepe Üniversitesi, ugursadi@hacettepe.edu.tr

${ }^{2}$ Arş. Gör., Hacettepe Üniversitesi, eserergonul@hacettepe.edu.tr

idealkent @ Kent Araştırmaları Dergisi (Journal of Urban Studies) 


\title{
Türkiye'de Kentsel Dönüşümün Anlamı, Aktörleri ve Amaçları
}

\author{
Uğur Sadioğlu ${ }^{3}$ \\ ORCID: 0000-0002-2454-4163
}

\author{
Eser Ergönül ${ }^{4}$ \\ ORCID: 0000-0002-3883-4129
}

\begin{abstract}
In the 2000s, important legal arrangements were made that directly and indirectly concern municipalities. While some laws are specifically regulated for a particular metropolitan area, the Municipal Law and the Metropolitan Municipality Law generally regulated the urban transformation practices of the municipalities. Finally, the Law No. 6306 of 2012 on the Transformation of Disaster Risk Areas has made various regulations through the central administration, the Ministry of Environment and Urbanization and TOKI. Regarding these regulations, the Ministry went to give both financial resources and authority and duties to TOKI and municipalities. Thus, many actors, such as district municipalities, metropolitan municipalities, ministries and administrations, are authorized to carry out important projects. $t$ is seen that the greatest role in this comprehensive and multidimensional policy field is given to the Ministry, subsequently to the metropolitan municipalities and finally to the district municipalities.

In this study, the legislation regulating this multi-actor and complex structure of urban transformation was examined. It is aimed to evaluate urban transformation applications, which have gained a negative image in recent years. As a result, the institutional framework in Turkey has been analyzed and interpreted.
\end{abstract}

Keywords: Urban transformation, Law no. 6306, urban transformation legislation, urban transformation institutions.

\footnotetext{
${ }^{3}$ Assoc. Prof., Hacettepe University, E-mail: ugursadi@hacettepe.edu.tr

${ }^{4}$ R. A., Hacettepe Univesity E-mail: eserergonul@hacettepe.edu.tr

idealkent @ Kent Araştırmaları Dergisi (Journal of Urban Studies) 


\section{Giriş}

Türkiye, 1980'li yıllardan itibaren dünyadaki gelişmelere paralel olarak yeni bir kentleşme dönemine girmiştir. Kentsel alanda oluşan zenginlik yerel, bölgesel, ulusal ve küresel aktörlerin ilgisini çekmektedir. Bu durum siyasal, sosyal, ekonomik ve kültürel baskı gruplarının aynı mekânda rekabet, iş birliği ya da çatışma zemininde bir araya gelmelerine yol açmıştır. Bu etkileşim içerisinde kentsel toprağın ve kentsel birikimin yeniden dönüştürülmesi temel nesne haline gelmiştir. Kentsel dönüşüm olarak nitelenen bu konu, Cumhuriyet döneminin kendine özgü kentleşme deneyimini yansıtan birçok şehrinde 2000'li yıllarda çok canlı bir şekilde gözükmektedir.

Türkiye örneğinde mevcut kent yönetimlerine miras kalan sağlıksız kentleşmenin sosyal kutuplaşma, fakirlik, mekânsal ayrışma, işsizlik, dengesiz gelir dağılımı, plansız yapılaşma, yetersiz sosyal hizmetler vb. sorunları (bkz. Yırtıcı, 2011) kentsel dönüşüm politikası bağlamında fiziksel dönüşümle birlikte değerlendirilmeyi ve çözülmeyi beklemektedir. Bir anlamda kentsel dönüşüm, kentsel alanlarda önceden izlenen ya da izlen(e)meyen politikaların sonucunda oluşmuş olan ekonomik, toplumsal, fiziksel ve çevresel çökme ve bozulmalara karşı ilgili politika aktörlerinin aradığı çözümler sepeti olarak görülmektedir (Akkar, 2006, s. 29). Bir başka bakış açısıyla kentsel dönüşüm, farklı politika araçlarıyla sınıfsal çatışmaları-çelişkileri sürdürmeye hizmet etmekte; yine yoksullar, yoksunlar ve marjinal kesimler kaybedenler olarak görülmektedir. Harvey'e göre (aktaran Akkoyunlu, 2014, s.206-207) kentsel dönüşüm, insanları mülksüzleştiren ve yerlerinden eden kapitalist kentsel süreçlerin temel bir özelliği olarak görülmektedir. Diğer bir yandan ise kentsel ekoloji kuramına göre 'şeylerin' mekânsal özellikleri olduğu iddia edilerek, mekânsal özelliklerin ise siyasal temellere sahip olduğu iddia edilmektedir ${ }^{5}$.

Literatürde kentsel dönüşüm anlayışının da değiştiği ve kapsamının genişlediği görülmektedir. Buna göre, yeni kentsel dönüşüm anlayışında geçmişten aktarılan kent sorunlarının çözümü yeterli bulunmamaktadır. Jeffrey ve Pounder'a göre "kent merkezlerinin yeniden canlandırılması, kentsel genişlemenin ve yayılmanın sınırlandırılması, çok işlevli kentsel alanların ve sürdürülebilir ulaşım tekniklerinin geliştirilmesi, doğal ve tarihi mirasın korunması gibi birçok ana politika başlığı, kent planlama gündeminde tartışımaya başlanmıştır" (aktaran Akkar, 2006, s.33). Görüldüğü üzere kentsel dönüşüm konusunda politika belirleyici ve planlayıcı aktöre önemli görevler

\footnotetext{
${ }^{5}$ Şikago ekolojik kent kuramına dair okumalar için Robert E. Park, Ernest W. Burgess ve R. D. McKenzie'nin eserleri başat yapıtlardır.
} 
yüklenmekte ve kendisinden beklentiler artmaktadır. Ancak diğer taraftan, farklı ülke örneklerinde yapılan güncel çalışmalara referanslarla, kamu politikası müdahalelerinin ve özellikle de planlamanın olumlu değişimler yapma yönündeki etki kapasitesi de sınırlı görülmektedir. Planlamanın önünde birçok farklı kaynaktan beslenen sınırlayıcıların bulunduğuna dikkat çekilmektedir (Campbell vd., 2014, s.46).

Türkiye'de, yukarıda kentsel dönüşümle ilgili olarak özetlenen yaklaşımlara benzer şekilde, 2000'li yıllarda belediyeleri doğrudan ve dolaylı olarak ilgilendiren önemli yasal düzenlemeler yapılmıştır (Ataöv ve Osmay, 2007, s.73; Demirkol ve Bereket Baş, 2013, s.2). Bazı kanunlar özel olarak belirli bir büyükşehir alanına ilişkin düzenlenmişken, Belediye Kanunu ve Büyükşehir Belediyesi Kanunu genel olarak belediyelerin kentsel dönüşüm uygulamalarını düzenlemiştir. Son olarak 2012 tarih ve 6306 sayılı Afet Riski Altındaki Alanların Dönüştürülmesi Hakkında Kanun; merkezi yönetim, Çevre ve Şehircilik Bakanlığı ve Başbakanlık Toplu Konut İdaresi Başkanlığı (TOKİ) üzerinden bu konuya hassasiyet göstermiştir (Keleş, 2013, s.400). Bu düzenlemelerle bizzat ilgili Bakanlık (Çevre ve Şehircilik Bakanlığı), TOKİ ve belediyelere hem parasal kaynak hem de yetki ve görev verilmesi yoluna gitmiştir. Fiziksel, ekonomik, çevresel olarak çöküntü alanlarına dönüşen kent merkezlerinin yeniden canlandırılıp ayağa kaldırılması için çıkarıldığı savunulan yasalar, verilen yetki ve imkânlar çerçevesinde zaman zaman amacının dışında kullanılmaya başlanmıştır. Maalesef büyük kentlerde buna sıkça rastlanılmakta, hatta küçük kent merkezlerinde 'dönüşüm uygulamaları' yok denecek kadar az gözükmektedir. Böylece kentsel dönüşüm konusunda ilçe belediyeleri, büyükşehir belediyeleri, bakanlık ve idareler gibi çok sayıda aktör önemli projeleri yürütmeye çalışmaktadır. Üzerinde durulan bu kapsamlı ve çok boyutlu politika alanında en büyük rolün Bakanlığa, devamında büyükşehir belediyelerine ve son olarak ilçe belediyelerine verildiği görülmektedir. Büyükşehir belediye sisteminde ilçe belediyesinin yapabileceklerinin sınırlı olduğu söylenebilir. Kentsel dönüşüm ile ilgili kanunların açıklandığı ilerleyen bölümlerde büyükşehir ilçe belediyelerinin kentsel dönüşüm uygulamalarında büyükşehir belediyesinin ve bakanlığın açtı̆̆ı alanda ancak uygulama yapabileceği anlatılmıştır.

Türkiye genelinde kentsel dönüşüm proje ve uygulamalarına bakıld1ğında olumsuz değerlendirmelerin yaygınlaşması kamuoyunda kentsel dönüşüme yönelik güven ve desteği azaltmaktadır. Bu konunun sağlıklı değerlendirmesini yapabilmek için çalışma kapsamında önce kavramsal ve kuram- 
sal çerçeve incelenmiş, devamında kentsel dönüşümün amaçlarına yer verilmiş ve son olarak Türkiye' deki kurumsal çerçeve analiz edilerek yorumlanmiştır.

\section{Kavramsal ve Kuramsal Çerçeve}

Kentsel dönüşümle ilgili muhakkak birçok kavram kullanılmakta ve tanımlanmaktadır. Burada dönüştürülmesi amaçlanan 'çöküntü bölgesi', izlenen strateji 'kentsel dönüşüm” ve bu ilgili uygulamaları kapsayan politikayı ifade eden 'kentleşme politikası' (kentleşme yöneltisi) kavramlarına açıklık getirilmiştir. Devamında ise kentsel dönüşüm ve ilgili diğer kavramlar tanımlanmıştır.

Birinci olarak çöküntü bölgesi, bir kentsel alan içerisinde yönetsel, toplumsal ve ekonomik araçlar ve sebeplerle gelişmesi engellenen, taşınmazlarının değerinde sürekli kayıplar olan, yoksulluk yuvası haline dönüşmekte olan veya dönüşmüş bölümlerdir (Keleş, 1998, s.37). Bu tanım içerisinde geçen yoksulluk yuvası ve onun temizlenmesine ilişkin terimler kentsel dönüşümle ilgilidir. Yoksulluk yuvasi/komşuluğu (slum), "Kalabalık, eski, yoğun nüfuslu, sıkışık yapılardan oluşan, halk sağlığı kurallarına uymayan düşük ölçünlü konutlardan oluşan ve anamalcı ülkelerin büyük kentlerinin özeklerinde rastlanan komşuluk birimleri"dir (Keleş, 1998, s.149). Yoksul komşulukların temizlenmesi" (slum clearance) ise, kentin estetiği ve planıyla uyumlu olmayan, çeşitli toplumsal, mekânsal ve fiziksel riskleri barındıran konut bölgelerinin yıkılarak, biçimi değiştirilerek ya da bu oluşumlara sebep olan koşullar giderilerek ortadan kaldırılmasıdır (Keleş, 1998, s.149-150). Kentsel ekolojik kuram mensuplarınca ise, çöküntü bölgeleri kent merkezlerinde mekânın doğası gereği vardır ve onları tamamen ortadan kaldırmak imkansıza yakındır (Park ve Burgess, 2015). Kent sosyolojisinde evrimsel olarak kentteki sosyal grupların farklı kent bölgelerinde yaşam çevrelerini inşa etmesi ve fiziki mekânın bu bağlamda sosyal, ekonomik, kültürel ve yapısal olarak yaşam kalitesi unsurlarının zayıflaması çöküntü bölgelerinin kaçınılmaz olduğunu göstermektedir. Kent merkezinin hemen yakın çevresindeki eski yapı stokundaki düşük kiralar sebebiyle şehirde var olan ya da göç ile yeni gelen "yoksul kesimleri" çekmesi bu süreci hızlandırmaktadır. Ankara Altındağ (Örnek Mahallesi) ve Mamak ilçelerindeki kent merkezine (Ulus, Sıhhiye, Kızılay) yakın mahallelerde eski, şehre ulaşımı kolay ve ucuz olan konutlara göçmenlerin yerleşmesi çöküntü alanı olma sürecini derinleştirmiştir. Eleştirel kurama göre ise, bu bölgelerde kamu politikası aktörleri 
planlı ya da plansız kamu hizmetleri ve altyapı yatırımları yapmayarak orta vadede oluşabilecek kent rantının dönüşümüne ortak olma amaciyla bu sürece gözlerini kapatmaktadır.

Kentsel dönüşüm kavramı kullanıldığında anlatılmak istenenin farklı kavramlara denk geldiği ve kavramın çok geniş içerikli olduğu görülmektedir. Bundan dolayı kentsel dönüşüm kavramını tanımladıktan sonra onunla ilgili bazı kavramları tanımlamanın faydalı olacağı düşünülmüştür: Kentsel koruma, kentsel sağlıklaştırma, kentsel yenileme, kentsel yeniden inşa, kentsel yeniden canlandırma, kentsel yeniden geliştirme, kentsel yeniden üretim.

İlk olarak Genel Türkçe Sözlük'te (TDK, 2016) kentsel dönüşüm, kentin imar planına uymayan, ruhsatsız binalarının yıkılıp, planlara uygun olarak toplu yerleşim alanlarının oluşturulması olarak tanımlanmaktadır. Türk Dil Kurumu aslında Türkiye'de genel olarak sadece 'toplu konut üretimi' ya da konut üretimine indirgenmiş kentsel dönüşüm uygulamasını yine dar anlamiyla tanımlamıştır.

İkinci olarak TÜBA Türkçe Bilim Terimleri Sözlüğü ise, kentsel dönüşüm kapsamı içerisinde değerlendirilebilecek birçok sorun alanını ve bunlara yönelik politika araçlarını içeren geniş bir tanımlama yapmıştır. Buna göre, bir şekilde bozulmaya uğramış alanların kentin gelişimine uygun biçimde yenilenmesini içeren eylemlerin tümü kentsel dönüşümdür (TÜBA, 2016).

Üçüncü olarak kentsel dönüşüm, bir olgu olarak yerleşme dokusunun değişik bölümlerinde, değişik nedenlerle, çok çeşitli yöntemler ve süreçlerle sürekli olarak gerçekleştirilmektedir. Bu olgu, kentlerdeki yaşam kalitesini önemli şekilde etkilemekte ve değişik sorunlar ile olanaklar sunmaktadır (Tekeli, 2011, s. 270). Kentsel dönüşüm, çökme ve bozulma olan kentsel mekânın ekonomik, toplumsal, fiziksel ve çevresel koşullarını kapsamlı ve bütünleşik yaklaşımlarla iyileştirmeye yönelik uygulanan strateji ve eylemlerin bütünüdür. Bu nedenle, kentsel dönüşüm, yeni kentsel alanların planlanması ve geliştirilmesinden çok, var olan kentsel alanların planlanması ve yönetimi ile ilgilidir (Akkar, 2006, s.29).

Kentsel dönüşüm geniş bir politika alanını ve çeşitli politika araçlarını kapsamaktadır. Burada kullanılan 'kentsel yenileme, sağlıklaştırma, imar-ıslah, yeniden canlandırma, soylulaştırma ve yayılma' gibi kentsel dönüşüm araçlarının kısaca açıklanmasına ihtiyaç vardır. Kentsel yenileme, kentin bir bölümündeki yapı stokunun yıkılıp yeniden yapılmasıdır. Kentsel sağlıklaştırma, eskimiş ve alt yapısı yetersiz kent dokusunun sınırlı iyileştirmeler ile işlevselliğini artırmaya yönelik çalışmalardır. İmar-ıslah çalışmaları ise, eskimiş ve sağliklaştırma gerektiren alanların bir de imar meşruiyetleri sorunu 
varsa uygulanmaktadır. Kentsel yeniden canlandırma (urban revival), sağlıklaştırma ve imar-ıslah çalışmalarıyla özellikle ekonomik sorunları çözülemeyen kent bölgelerinin ekonomik hayatlarını geliştirmek için yapılan dönüşüm çalışmalarıdır. Soylulaştırma, mimari değer ya da sembolik kent kimliğine sahip korunma alanlarında, fiziki yapıyı ve çevreyi korumak için bu bölgelerdeki sosyal tabakayı değiştirmeye yönelik izlenen yol ve yöntemdir. Yayılma, kentin çevresindeki kırsal alanların kent işlevlerinin kullanımına açılarak dönüşmesini ifade etmektedir (Tekeli, 2011, s.275-277).

Bunlara ek olarak kentsel koruma, "kentlerin belli kesimlerinde yer alan çağbilimsel ve yapıtasarcılık değerleri yüksek yapıtlarla, anıtların ve doğa güzelliklerin -kentte bugün yaşayanlar gibi- gelecek kuşakların da yararlanması için her türlü yıkıcı, saldırgan ve dokuncalı eylemler karşısında güvence altına alınması" (Keleş, 1998, s.93) olarak tanımlanmıştır. Kentsel yeniden geliştirme ise, "ekonomik ve yapısal özellikleri, iyileştirilmesine olanak vermeyecek ölçüde kötüleşmiş olan yoksul konutlarının yıkılması ve bunların oluşturduğu kent bölümlerinin yeni bir tasarlama düzeni içinde bayındırılması"dır (Keleş, 1998, s. 139). ABD'de 1954 yılında yasalarda geçen kentsel dönüşüm terimi yerine kentsel yeniden geliştirme terimi kullanılmaya başlamıştır. Böylece yasanın kapsamı kötüleşme potansiyeli olan alanlar ve bölgeler olarak genişletilmiştir (Weber, 2002, s.527).

Kentsel yeniden üretim, dünya genelinde yapıların artan bozulma ve çürüme durumları nedeniyle ilgi çeken bir kavram ve politika aracıdır. Kentsel yeniden üretim kavramı, kentsel yenileme, kentsel yeniden geliştirme, kentsel sağlıklaştırma ve kentsel yeniden canlandırma kavramlarıyla birlikte ya da yerine kullanılmaktadır. Ancak, kentsel yeniden üretim var olan yapıların sağlıklaştırılmasını, yapıların ve bölgelerin yeniden geliştirilmesini ve kentsel toprağın yeniden kullanımını içeren bir süreçtir. Yıkma ve temizleme şeklinde bir yöntem yerine, kentsel yeniden üretim karmaşık bir süreçtir. Bozulmuş yapılar ve toplumsal dokular kentsel yeniden üretim kapsamındaki çeşitli yöntemlerle geliştirilmektedir. Yani fiziksel yapıların iyileştirilmesine ek olarak, özel bir vizyonla tıkanmış trafik, yetersiz açk alan ve kent alt yapısı gibi kent sorunları da çözüme kavuşturulmaktadır. Bunlara ek olarak, kentsel yeniden üretim yeni iş imkanları yaratarak, sosyal ağları genişleterek, gönüllü grupların aktif katılımını sağlayarak ekonomik ve sosyal faydalar sağlamaktadır. Aynı zamanda sürdürülebilirlik kentsel yeniden üretim sürecinin üzerinde durduğu ekonomik, ekolojik ve sosyal bir alandır (Peng vd., 2015, s.76). 
Kavramsal açıklamalardan anlaşıldığı üzere kentsel dönüşüm, kentin mekânsal ve onunla ilişkili alanlarında oluşagelmiş olumsuzlukların bütüncül bir politika, plan ve programla giderilmesi çalışmalarını ifade etmektedir. Bu konunun ülkemizde sorunlu hale gelmesi ve sorunun çözülmesi iddiası ile yürütülen çalışmaların yeni sorunları beraberinde getirmesi en başta tanımın ve bu tanım üzerinden girişilen projelerin sorunları olduğunu göstermektedir.

Türkiye gerçeği düşünüldügünnde sihirli bir kelime gibi kent yaşamına giren kentsel dönüşüm kavramı, kent merkezlerindeki ekonomik canlılığını yitirmiş tarihi alanları yeniden ayağa kaldırmak; fiziksel, ekonomik, toplumsal bozulmanın önüne geçmek veya kent planlaması için etkin bir araç olarak kullanılmaktan ziyade yanlış uygulamalar nedeniyle toplum hafızasında 'olumsuz anlam' ifade etmeye başlamıştır. Aslında kentsel dönüşüm toplumun mekân üzerinde ortaya koyduğu ve ondan beslendiği kültürel birikimin sürdürülebilmesi, kimlik unsurlarını muhafaza etmesi ve yeni sosyal grupların kendilerini kente ait hissetmesi için birçok imkân sunmaktadır.

\section{Kentsel Dönüşümün Amaçları}

Kentsel dönüşüm amaçlarına çerçeve kazandıran ve yön veren önemli kent sorunları vardır. Bu nedenle amaçları anlamak üzere kısaca kentsel dönüşümün nedenlerine bakmak gerekmektedir: Bunlardan en önemlisi, gerek iç ve dış göç, gerekse de doğal olarak kent nüfusundaki artışı süreklilik arz etmesi ve bunun da artık büyükşehirlerde kaçınılmaz bir kabul halini almış olmasıdır. Nüfusun artışına bağlı kentleşme gelişmekte olan ve azgelişmiş ülkelerin devam eden bir olgusudur. Kırsal alan itici etmenleri (arazilerin parçalanması, tarımsal gelirin düşüklüğü, üretim maliyetlerinin artması, yetersiz kamu hizmetleri, güvenlik sorunları vb.) ve kentlerin çekici etmenleri (istihdam, kamu hizmetleri, kent hizmetleri, hareketlilik, kültürel çeşitlilik vb.) büyükşehirler özelinde kentleşme sürecini zorlamaya devam etmektedir. Bu dinamik kentteki toprağın değerini artırmakta ve rant beklentisi dönüşümü zorlamaktadır. İkinci olarak, küreselleşme kentleri ulusal sınırların dışına taşımış ve kent ekonomisinin dünya ekonomisiyle ilişkilerini ve etkileşimini yoğunlaştırmıştır. Ticaret, üretim ve hizmet hacminin artması, kentli nüfusun refahının artması, tüketim kalıplarının değişmesi ve altyapının yetersizliği sonucunda kentin merkezi ve çevresi dönüşüm baskısı altına girmiştir. Üçüncü olarak, ekonomik gelişme sosyal, kültürel, siyasal ve teknolojik gelişmeleri beraberinde getirerek konuttan altyapıya, kullanılan ulaşım ve iletişim 
teknolojileri alt yapısına, sosyal, kültürel ve eğitim donatılarına kadar yeni bir dönüşümü gerektirir. Dördüncü olarak, yapıların eskimesi ya da estetik değerlendirmeler ile yeni yapıların tercih edilmesi özellikle konut alanlarını dönüştürme talebi doğurabilir. Beşinci olarak, afet riskleri ve yaşanılan ağır kayıpların beslediği kaygılar kentsel dönüşümü güçlendirebilir. Birçok sorun sıralanabilir ve en önemlisi tüm bu sorun veya nedenlerin birbirleriyle ilişkili olarak kentsel dönüşüme etki edebileceğidir (Tekeli, 2011, s.272-273).

Kentsel dönüşümün genel olarak nedenlerini bu zemine oturttuğumuzda amaçlar anlam kazanmaktadır. Roberts'a (2000) (aktaran Akkar, 2006, s.2930) göre, kentsel dönüşüm, beş temel amaca hizmet etmek üzere ortaya çımıştır. Bunlar; kentin fiziksel koşulları ile toplumsal problemleri arasında ilişki kurulması, kentin dokusunu oluşturan öğelerin fiziksel olarak değişime ihtiyaç duyması, başarılı bir ekonomik kalkınma gerçekleştirmek, kentsel alanların en etkin biçimde kullanılmasını sağlamak ve toplumsal koşullar ile politik güçlerin ürünü olarak kentsel politikanın şekillendirilme ihtiyacını karşılamaktır (Akkar, 2006, s.29-30).

Günümüzde kentsel dönüşümün amaçları sürdürülebilir kalkınma, yaşanabilirlik ve refah düzeyini yükseltme, yerel hizmetler ve kamu hizmetlerine yeterli düzeyde erişebilirlik, katılımcılık ve yönetişim, kent estetiğini gözetme gibi sosyal, kültürel, mekânsal, ekonomik, siyasal ve yönetsel nitelikte geniş bir yelpazeyi andırmaktadır. Bu amaçların gerçekleştirilmesinde çok farklı aktörler çeşitli düzeylerde politika belirleme ve uygulama süreçlerinde yer almaktadır. Gelişmiş demokratik ülkelerde kentsel dönüşüm politikalarının birincil aktörü yerel yönetimler ve paydaşları olsa da, sorunun karmaşıklaştığı ve yerel kaynaklarla baş edilemediği ülkelerde merkezi yönetim ve ilgili kurumları öne çıkmaktadır.

Avrupa'da kentsel dönüşüm politikasının kısa tarihine bakıldığında üç dönemde farklı aktörlerin değişen rolleriyle karşılaşılmaktadır: Birinci dönem, II. Dünya Savaşı'nın hem sonrasında başlayan savaşın kentlerdeki yıkımını onarmaya çalışan süreci kapsamaktadır. Bu dönemde var olan şehirlerin merkezleri neredeyse tamamen yeniden yapılandırılmış ve geleceğe hazırlanmıştır. Birinci dönemde merkezi hükümetler en büyük rolü oynamışlardır. İkinci dönem, 1970'li yıllarla başlayan, yeni kitlesel hareketlerin etkisiyle kentlilerin planlama ve kentin yeniden yapılanmasında yer almasını sağlayan süreci kapsamaktadır. Bu dönemde merkezi hükümetler, amaçları ve politikaları belirlemiş ve mali kaynaklar sağlamış; büyükşehirlerdeki belediyeler ise planlama ve uygulama sorumluluğunu üstlenmişlerdir. Üçüncü dö- 
nem, 1990'lı yıllarla başlayan ve politikaların yeni bir yolla geliştirilmesini içeren süreci kapsamaktadır. Toplumun değişen ve çeşitlenen dokusuna uygun olarak konut alanında farklı birikim modelleri ortaya çıkmıştır. Bu dönemde iki yaklaşım görülmüştür: 1) Sosyal konutların olmadığı alanlarda sosyal konutların oluşturulması; 2) Sosyal konutların yoğun olduğu alanlarda ise sosyal konutların orta sınıf konutlarıyla değiştirilmesini sağlama. Üçüncü dönemde merkezi hükümet kentsel yenileme politikasındaki liderlik rolünü kaybetmiştir. Ancak, merkezi hükümetler bütçe ve politika geliştirme sorumluluğunu ellerinde tutmaya devam etmektedirler. Önemli ölçüde kamu-özel ortaklıkları artarken, çok aktörlü karar verme süreçlerine ve kent sakinlerinin karar verme sürecine dahil edilmesine yönelik yaklaşım gelişimi görülmektedir (Wassenberg, 2013).

Örneğin, Avrupa Birliği (AB) ülkelerinde artık kentlerin ve özellikle metropoliten bölgelerin kent planlaması ve kentleşme politikasında önemli belirleyici aktörlerden birisi $\mathrm{AB}$ organları ve kurumları olmuştur. Bu yeni durum kent yönetimlerinin politika belirleme süreçlerinde bazı sınırlamalar sunsa da, bazı fırsatlar da geliştirmektedir. Politika belirleme anlamında çok düzeyli yönetişimin metropoliten kentler için de belirleyici bir yeni anlayış olduğu söylenebilir. Çok düzeyli yönetişim içerisinde metropoliten yönetim, bölgesel yönetim (meso-region), ulus devlet ve AB vardır. Salet ve Thornly (2007, s.191-192), metropoliten politikaların belirlendiği üç eylem alanını tanımlamışlardır: 1. Özel sektör ağları, bu ağlar içerisinde uluslararası ve yerel sosyal ve ekonomik çeşitlilik gösteren örgütler ve örgüt grupları yer almaktadır. 2. Bölgelerarası politika ağları, bu ağlar içerisinde uluslararası, ulusal ve bölgelerarası politika programları vardır. 3. Bölgeiçi ağlar, bu ağlar metropoliten bölge düzeyinde yerleşik yerel ve bölgesel politika yapımında bulunan çeşitli inisiyatiflerdir.

Türkiye'de 2000'li ylllarda bu anlamda melez bir görüntü oluşmuştur. Bir taraftan kentsel planlamanın sorumluluğunu taşıyan belediyeler, diğer taraftan Başbakanlık Toplu Konut İdaresi Başkanlığı (TOKİ) ve Çevre ve Şehircilik Bakanlığı (ÇŞB) farklı düzeylerde ayrı veya iş birliği içerisinde kentsel dönüşüm politikasının taraflarıdır. Cumhurbaşkanlığı Hükümet Sistemi ile Cumhurbaşkanı da sürece dahil edilmiş ve TOKİ'nin ÇŞB'ye bağlanmasıyla yeni bir kurumsal görüntü oluşmuştur. Yeni durumun belediyeler ve merkezi yönetim aktörleri üzerinden yönetişim yaklaşımıyla yorumlanması kentsel dönüşüm uygulamalarını güçlendirecektir. Ayrıca, farklı kanunların düzenlediği bir alanda yetki, görev ve sorumlulukların iyi açıklanması sistemin işleyişine ve anlaşılmasına katkı sunacaktır. 


\section{Kentsel Sürdürebilirlik ve Kentsel Dönüşüm}

Sürdürülebilir kentsel gelişme yaklaşımı, sürdürülebilirliğin temel dört bileşeni olan sosyal içerik, ekonomik olma, çevresel değerlere saygı ve teknolojik gelişmelere uyarlanabilir olma konularının tümünü kapsamaktadır. Kentte yaşayan bütün bireylerin (engelliler, yaşlllar, çocuklar, dar gelir grubunda yer alanlar, kadınlar vb.), kentin sunduğu kamusal hizmetlerin tümüne eşit düzeyde ulaşabilmesi anlamına gelen 'kentsel erişilebilirlik' (accessibility) kent yaşamı için amaçlanması gereken önemli bir sosyal sürdürülebilirlik bileşeni durumundadır.

Sürdürülebilir kalkınma ve sürdürülebilirlik kavramının sıkça konuşulmaya başlandığ 1 1980'li ve 1990'lı yıllarda sürdürülebilirliğin bileşenlerinden birisi olan sosyal sürdürülebilirlik çok fazla ilgi görmemiştir (Dawe ve Ryan, 2003). OECD'nin (2001) sürdürülebilirlik konusuna bakışında, sürdürülebilirliğin sosyal boyutunun asıl bileşen olmaktan çok çevresel boyutun bir alt bileşeni gibi görüldüğünden bahsedilmektedir. Portney'in (2003) ABD'de 32 kenti içeren çalışmasında, sürdürülebilir kent olgusunda sosyal boyutun çok fazla öne çıkmadığına vurgu yapılmaktadır. Scott (2008, s.769), benzer şekilde nüfusunun $\% 75$ 'inden fazlası metropollerde yaşayan $\mathrm{ABD}$ büyük şehirlerinde üç temel politika ve planlama inisiyatifinin bulunduğunu belirtmektedir. Bunlardan birincisi, yeni kent ekonomisindeki yerel rekabet edebilirlik avantajını kullanmak için kurumların koordine edilmesi; ikincisi, büyük kent topluluklarında demokratik uçurum sorununu gidermek için mekanizmalar inşa edilmesi; üçüncüsü ise, kent içi alan yapısı ile kent yönetişimi kurumları arasındaki uyuşmazlığın giderilmesidir. Fakat Scott (2008, s.770), bu tür neoliberal pragmatist kent politikası ve planlaması bakışı ve araçlarının yetersiz olduğunu vurgulamakta ve sosyal eşitsizlik sorunu gibi sosyal içerikli konuların ve adalet ve tarafsızlık gibi ilkelerin de politikaya dâhil edilmesi gerektiğini savunmaktadır.

Buradan hareketle artık birçok ülkede kent planlamasında park ve rekreasyon alanlarının oluşturulması, kültürel hizmetler sunulması ve alanların geliştirilmesi, güvenlik sağlanması, yoksulluğun azaltılması, eşitliğin sağlanması, engellilerin yaşamlarının kolaylaştırılması, erişilebilirlik gibi konular başta olmak üzere sürdürülebilirliğin sosyal boyutu oldukça önemli hale gelmiştir (Holden, 2012, s.529). Curry'nin (2012, s.96-97) Büyük Britanya örneğinde yaptığı sürdürülebilir gelişme politikası analizinde önem verilmesi gereken farklı konular ile karşılaşılmaktadır: Özelikle bugüne değin izlenen 
kentleşme politikasının kent merkezli olması, kırsal olanın sürdürülebilir gelişmesini ihmal etmiştir. Kent merkezli sürdürülebilir gelişmenin üç temel unsuru vardır: Birincisi, özellikle otomobil kullanarak sağlanan ulaşım ihtiyacını azaltmak; toplu taşımayı arttırarak insanların işyerlerine, hizmetlere, alış-veriş mekânlarına ulaşımını kolaylaştırmak ve karbon emisyonunu azaltmak için bisiklet kullanımını ve yürümeyi teşvik etmek. İkincisi, kentlerde gelişmişliği arttırmaktır. Bu genel bir ilke olsa da, konut üretimi gelişimine vurgu artmıştır. Üçüncüsü ise mevcut durumda gelişmiş olan alanların gelişmişliğini en üst düzeye çıkarmaktır. Yeşil alanların korunması da buna dâhil edilmektedir. 2010-2011 tarihli Localism Kanunu birçok konuda olduğu gibi kentleşme politikasında desantralizasyon amaçlayarak planlama, konut üretimi, yerel topluluğun güçlendirilmesi ve kırsal alandaki toprak kullanımı planlamasının reforma tabi tutulmasını ilişkilendirmiştir.

Kentsel dönüşüm projelerinde sürdürülebilir gelişme yaklaşımının belirleyici olması önemli bir adımdır, ancak yeterli değildir. Politika içeriği ve belirleme süreci kadar politika uygulama süreci ve unsurlarına ilişkin düzey de önemlidir. Burada örgütsel kapasite kavramı öne çıkmaktadır. Örgütsel kapasite, stratejilerin ve politikanın geliştirilmesinden önce, temel ihtiyaçların belirlenmesi adımından politikanın uygulanması ve sonuçların değerlendirmesi adımına kadar kapsayıcı bir süreci ifade etmektedir. Örgütsel kapasitenin analitik çerçevesinde 'Liderlik, Vizyon, Stratejik Ağlar, Sosyal Destek, Siyasal Destek ve İletişim' gibi araçlar vardır. Uzun dönemli bir kentsel sürdürülebilir gelişme politikasının stratejileri, programları ve projeleri yeterli bir liderlik tarafından sahiplenir ve etkili bir şekilde yürütülür; politikaları geliştirmek ve başarılı bir şekilde uygulamak için ilgili paydaşlardan oluşan stratejik ağlar oluşturulur ve destekleri alınır; kent yönetimi içerisinde ve çevresindeki hemşeriler, özel sektör unsurları, kamu kurum ve kuruluşları ve diğer ilgili aktörlerle uygun iletişim stratejileri ile sosyal ve siyasal destek sağlanır (Berg vd., 2003, s.1961-1962). Günümüzde kentsel dönüşüm politikasıyla ilişkili olan tüm aktörlerin yeterli bir örgütsel kapasiteye sahip olması kaçınılmazdır. Aksi halde, sürdürülebilir kentsel gelişme anlayışının politika belgelerinde yer bulması yeterli olmayacaktır.

Bu konudaki uygulama ve akademik birikime göre kentsel dönüşüm anlayışının da değiştiği ve kapsamının genişlediği görülmektedir: Buna göre, yeni kentsel dönüşüm anlayışında geçmişten aktarılan kent sorunlarının çözümü yeterli bulunmamakta, "kent merkezlerinin yeniden canlandırılması, kentsel genişlemenin ve yayılmanın sınırlandırılması, çok işlevli kentsel alan- 
ların ve sürdürülebilir ulaşım tekniklerinin geliştirilmesi, doğal ve tarihi mirasın korunması gibi birçok ana politika başlığı, kent planlama gündeminde tartışılmaya başlanmıştır" (Jeffrey ve Pounder, 2000'den aktaran: Akkar, 2006, s. 33). Sürdürülebilirlik sadece hizmetler, mallar ya da yapılarla ilgili bir konu değildir. Daha önemlisi sürdürülebilir kent, çevreyle ve toplumla ilişkilidir. Sürdürülebilir toplumların ihtiyaç duyduğu önemli bir bileşen sürdürülebilir yapılardır. Bu yapıların tümü de aslında kültür birikiminin sürdürülebilmesine imkân sağlayacaktır (McDonald, 2012).

Bu nedenle özellikle tarihi ve kültürel varlığa yönelik projelerde muhakkak yerel yönetimlerin birincil aktör olması ve yerel topluluğun projelere dahil olması önemlidir (Lenger, 2012, s.6-8). Ancak, kent kimliği konusu öne geldiği zaman, kentin hangi bölgesinin, hangi toplumsal sinıfın, hangi kültürel birikimin ifade edildiği doğru bir şekilde ortaya konulmalıdır (Rapoport, 1983). Kentin kültürel mirasına modern dönemde özellikle kentteki orta sınıf etkide bulunmaktadır. Hayırseverlik ve gönüllü kuruluşların mali destekleri görmezden gelinemeyecek kadar yüksektir (Lenger, 2012, s.190-194). Hatta buradaki bakış açısının sadece düşünce alma şeklinde değil, doğrudan halkın kent politikasını belirlemesi ya da karar alıclara öğretmesi olarak değişmesi gerekir. Bunun için birçok politika aracı, teknolojik gelişme ve yaklaşım vardir (Campbell ve Corley, 2012).

Türkiye'de kentsel dönüşüm konusunda birçok aktör vardır. Kurumsal çevrenin analizi sürdürülebilir kentsel gelişme için yeterli bir örgütsel kapasitenin varlığını yorumlamaya yardımcı olacaktır.

\section{Türkiye'de Kentsel Dönüşümün Kurumsal Çevresi}

Türkiye'de kamu sektörünün ve özel sektörün iş birliği içerisine girdiği ve zaman zaman da sivil toplum örgütlerinin desteğinin alındığı kentsel dönüşüm dönemine girilmiştir. Ortaklaşa Yönetim (Yönetişim) anlayışı kapsamında Ankara'da Portakal Çiçeği Vadisi ve Dikmen Vadisi projeleri, İstanbul'da Kuştepe Kentsel Dönüşüm Projesi örnek gösterilmektedir. Portakal Çiçeği Vadisi ve Dikmen Vadisi projelerinde 'imar haklarının toplulaştırılması' (hamur) yönteminden yararlanılmışken; Kuştepe Kentsel Dönüşüm Projesi'nde 'imar haklarının aktarımı' yönteminden yararlanılmıştır. Her iki yöntem de hukuk sistemimizi zorladığı için düzenlemelere ihtiyaç duyulmuştur (Keleş, 2013, s.388). Türkiye'de kentsel dönüşüm uygulamalarında kentsel dönüşüm yöntemi açısından çok farklı örnekleri görmek mümkündür. 
Tablo 1. Kentsel Dönüşüm Yöntemleri ve Uygulamadan Örnekler

\begin{tabular}{|c|c|}
\hline $\begin{array}{l}\begin{array}{l}\text { Yenileme } \\
\text { (renewal) }\end{array} \\
\end{array}$ & $\begin{array}{l}\text { Kuzey Ankara Kentsel Dönüşüm Uygulamasi; Cizre ve } \\
\text { Nusaybin Uygulamaları }\end{array}$ \\
\hline $\begin{array}{l}\text { Sağllklaştırma } \\
\text { (rehabilitation) }\end{array}$ & $\begin{array}{l}\text { Ankara, Altındağ, Hamamönü İnci ve Dutlu Sokak Sağlık- } \\
\text { laştırma Projesi }\end{array}$ \\
\hline $\begin{array}{l}\text { Koruma } \\
\text { (conservation) }\end{array}$ & Ankara Kalesi Koruma Geliştirme Projesi \\
\hline $\begin{array}{l}\text { Yeniden canlandırma } \\
\text { (revitalization) }\end{array}$ & $\begin{array}{l}\text { Ankara Hamamönü, Beypazarı ve Safranbolu Canlan } \\
\text { dırma Projeleri, Konya Bedesten Uygulaması }\end{array}$ \\
\hline $\begin{array}{l}\text { Yeniden geliştirme } \\
\text { (redevelopment) }\end{array}$ & Ankara Gültepe (Çinçin) Örneği \\
\hline $\begin{array}{l}\text { Düzenleme } \\
\text { (improvement) }\end{array}$ & $\begin{array}{l}\text { Florida Pompano Beach Konut ve Kent Düzenleme Prog } \\
\text { ramı }\end{array}$ \\
\hline $\begin{array}{l}\text { Temizleme } \\
\text { (clearance) }\end{array}$ & $\begin{array}{l}\text { 1850-60 yılları arasında Paris Kentsel Temizleme Uygula- } \\
\text { ması; } 1970 \text { 'li yıllarda Rio de Janeiro Uygulaması; İzmir Ka- } \\
\text { difekale Uygulaması }\end{array}$ \\
\hline $\begin{array}{l}\text { Yeniden üretme } \\
\text { (reproduction) }\end{array}$ & 1980'li yıllarda Güney Kore Uygulamaları \\
\hline $\begin{array}{l}\text { Kalitenin yükseltilmesi } \\
\text { (quality improvement) }\end{array}$ & $\begin{array}{l}\text { 1990'li yıllar ve devamında Güney Amerikan kentlerinde } \\
\text { izlenen strateji (Bogota, Rio de Janeiro, vb.) }\end{array}$ \\
\hline $\begin{array}{l}\text { Soylulaştırma } \\
\text { (gentrification) }\end{array}$ & Ankara Dikmen Vadisi Kentsel Dönüşüm Projesi \\
\hline \multicolumn{2}{|l|}{$\begin{array}{l}\text { Boşlukları doldurarak geliştirme } \\
\text { (infill development) }\end{array}$} \\
\hline $\begin{array}{l}\text { Tazeleme-parlatma } \\
\text { (refurbishment) }\end{array}$ & \\
\hline
\end{tabular}

Tablo 1'de Türkiye'den ve diğer ülkelerden örnekler ile kentsel dönüşüm yöntemlerinin ilişkilendirilmesi yapılmıştır. Bu ilişkilendirme, yönetimin tanımı ve uygulamalarının birebir örtüşmesi olarak görülmese de, yöntemler hakkında genel fikir vermektedir. Bazı kentsel dönüşüm yöntemlerine örnekler henüz verilememiştir.

Kentsel dönüşüm konusunun da içinde olacağı yeni bir kanun çalışması 2000'li yılların başına yapılmış olsa da, böyle kapsamlı bir kanun düzenlenmemiş, kentsel dönüşüme ilişkin düzenlemeler önce parça parça çıkmıştır. 2004 yılında Bayındırlık ve İskân Bakanlığı kentsel dönüşüm konusunda kapsamlı bir kanun taslağı hazırlamıştır. Bu kanun taslağında, kentsel dönüşüm alanı tanımlanmış; kentsel dönüşüm planı imar mevzuatına uygun öngörülmüş, belediyelere ve valiliklere "hamur yetkisi" tanınmış, kamu ortaklık payı \%10 olarak öngörülmüştür. Bu taslak, bazı değişikliklerle 2010 y1lında Hükümet tarafından TBMM'ye getirilmiştir. Bu taslakta yer alan hususlar 2004, 2005 ve 2006 yıllarında farklı kanunlarda yer almıştır: 


\section{4 tarih ve 5104 sayılı Kuzey Ankara Girişi Kentsel Dönüşüm Projesi}

\section{Капипи}

İlk ve özel bir düzenleme 2004 tarih ve 5104 sayılı Kuzey Ankara Girişi Kentsel Dönüşüm Projesi Kanunu'dur (Resmi Gazete, 12.03.2004, Say1: 25400). “Bu Kanunun amac1, kuzey Ankara girişi ve çevresini kapsayan alanlarda kentsel dönüşüm projesi çerçevesinde fiziksel durumun ve çevre görüntüsünün geliştirilmesi, güzelleştirilmesi ve daha sağlıkı bir yerleşim düzeni sağlanması ile kentsel yaşam düzeyinin yükseltilmesidir" (md. 1). Bu Kanun kapsamında sadece Kuzey Ankara Girişi Kentsel Dönüşüm Projesi alan sınırları içindeki her tür ve ölçekteki planlar, inşa edilecek resmi ve özel her türlü yapı, altyapı ve sosyal donatı düzenlemeleri ve kamulaştırma işlemleri, usul ve esaslar yer almaktadır (md. 2). Kanun özel olarak Ankara ilinin belirli bir alanına (Protokol Yolu Sınır Krokisi'nde gösterilen alan) özgü düzenlenmiştir ve bundan dolayı Toplu Konut İdaresi Başkanlığı'nı (TOKİ), TOKİnin bağlı olduğu Bakanlığı, Ankara Büyükş̧ehir Belediyesini, Altındağ ve Keçiören Belediyelerini kurumsal olarak yetkilendirmiştir. "Proje alanında her ölçekteki imar planları Belediyece yapılır, yaptırılır ve onanır". (md. 4) cümlesi 2006 tarih ve 5481 sayılı Kanun ile eklenmiştir. Buradaki belediye Ankara Büyükşehir Belediyesidir. Proje uygulaması tamamlandıktan sonra, Ankara Büyükşehir Belediyesi'nin bu Kanundan kaynaklanan yetkilerinin ilgili mevzuatına göre ilçe belediyeleri ve diğer kamu kuruluşlarına devredileceği düzenlenmiştir (md. 4).

2006 tarih ve 5481 sayılı Kanun ile yapılan değişiklik ile Kanun'un proje yönetimine ilişkin yetki ve sorumluluk ilişkilerinde değişiklik yapılmıştır. Buna göre, “Proje alan sınırlarındaki kentsel tasarım projeleri ile konut, sosyal donatı, çevre düzenlemesi, teknik altyapı projeleri, müşavirlik ve kontrollük hizmetleri ile yapım dahil diğer işler Belediye ve İdare tarafından, Bakanlıkça tespit edilecek görev dağılımına göre yapılır veya yaptırılır" (md. 6). Böylece, Ankara Büyükşehir Belediyesi ve TOKİ'nin proje sürecindeki görev bölüşümü Bakanlık tarafından belirlenecektir. 
Tablo 2. Türkiye'de Kentsel Dönüşümün Yasal Dayanakları

\begin{tabular}{|c|c|}
\hline Yasal Dayanak & Amaç ve Kapsam \\
\hline $\begin{array}{l}2004 \text { tarih ve } 5104 \text { sayılı Kuzey Ankara Girişi } \\
\text { Kentsel Dönüşüm Projesi Kanunu }\end{array}$ & $\begin{array}{l}\text { Kuzey Ankara girişi ve çevresini kapsamakta, } \\
\text { bu bölgenin fiziksel durum ve çevre görüntüsü- } \\
\text { nün geliştirilmesini ve kentsel yaşam düzeyinin } \\
\text { yükseltilmesini amaçlamaktadır. }\end{array}$ \\
\hline $\begin{array}{l}2005 \text { tarih ve } 5366 \text { sayılı Yıpranan Tarihi ve Kül- } \\
\text { türel Taşınmaz Varlıkların Yenilenerek Korun- } \\
\text { ması ve Yaşatılarak Kullanılması Hakkında Ka- } \\
\text { nun }\end{array}$ & $\begin{array}{l}\text { Büyükşehir, büyükşehir ilçe, il ve ilçe belediye- } \\
\text { leri ile nüfusu } 50.000 \text { 'in üzerindeki belediyeler } \\
\text { ile il özel idarelerini yetkilendirmektedir. Sit } \\
\text { alanlarında ve bu bölgelere ait koruma alanla- } \\
\text { rındaki yapıların yeniden inşa ve restore edil- } \\
\text { mesi, bu bölgelerde yeni donatı alanları oluştu- } \\
\text { rulması, tarihi ve kültürel taşınmaz varlıkların } \\
\text { yenilenerek korunması ve yaşatılarak korun- } \\
\text { ması amaçlanmaktadır. }\end{array}$ \\
\hline $\begin{array}{l}2005 \text { tarih ve } 5393 \text { sayılı Belediye Kanunu'nun } \\
\text { 73. maddesi }\end{array}$ & $\begin{array}{l}\text { Belediye, belediye meclisi kararıyla, konut, sa- } \\
\text { nayi, ticaret alanları, teknoloji parkları, kamu } \\
\text { hizmeti, rekreasyon, her türlü sosyal donatı } \\
\text { alanları oluşturmak, eskiyen kent bölgelerini ye- } \\
\text { niden inşa ve restore etmek, kentin tarihi ve kül- } \\
\text { türel dokusunu korumak veya deprem riskine } \\
\text { karşı tedbirler almak amacıyla kentsel dönüşüm } \\
\text { ve gelişim projeleri uygulayabilir. Kentsel dö- } \\
\text { nüşüm ve gelişim proje alanı büyüklüğünün en } \\
\text { az } 5 \text { en çok } 500 \text { hektar arasında olması şarttır. }\end{array}$ \\
\hline $\begin{array}{l}2012 \text { tarih ve } 6306 \text { sayılı Afet Riski Altındaki } \\
\text { Alanların Dönüştürülmesi Hakkında Kanun }\end{array}$ & $\begin{array}{l}\text { Bu Kanunun amacı, afet riski altındaki alanlar } \\
\text { ile bu alanlar dışındaki riskli yapıların bulun- } \\
\text { duğu arsa ve arazilerde, fen ve sanat norm ve } \\
\text { standartlarına uygun, sağlıklı ve güvenli ya- } \\
\text { şama çevrelerini teşkil etmek üzere iyileştirme, } \\
\text { tasfiye ve yenileme çalışmalarını düzenlemek- } \\
\text { tir. Riskli alan, kanunda sayılan hallerde mahalli } \\
\text { idarelerin ya da ÇŞB'nin başvurusu üzerine “ze- } \\
\text { min yapısı veya üzerindeki yapılaşma sebebiyle } \\
\text { can ve mal kaybına yol açma riski taşıyan, Cum- } \\
\text { hurbaşkanınca kararlaştırılan alandır. }\end{array}$ \\
\hline
\end{tabular}

2005 tarih ve 5366 sayıl Yıpranan Tarihi ve Kültürel Taşınmaz Varlıkları Yenilenerek Korunması ve Yaşatılarak Kullanılması Hakkında Kanun

İkinci olarak, 2005 tarih ve 5366 sayılı Yıpranan Tarihi ve Kültürel Taşınmaz Varlıkların Yenilenerek Korunması ve Yaşatılarak Kullanılması Hakkında Kanun'da kentsel dönüşüm konusu düzenlenmiştir. Bu Kanunun gerekçesine bakıldığında, 
"kentin kültürel miras değerini korumak, sosyal donatı alanlarını büyütmek ve sağlıklaştırmak, otopark sorununu çözüme kavuşturmak, günümüzün kullanım ihtiyaçlarına cevap verecek konut, ticaret, kültür, turizm ve sosyal donatı alanları oluşturmak, tarihi ve kültürel dokuyu restore ederek kullanmak, kent merkezlerindeki denetimsiz bölgelerdeki güvenlik sorunlarını çözerek kullanılabilir hale getirmek"

amaçları ilişkili bir şekilde sıralanmıştır. 5366 sayılı Kanun, büyükşehir belediyelerini, büyükşehir ilçe belediyelerini, il ve ilçe belediyelerini, nüfusu 50.000 'in üzerinde olan belediyeleri, il özel idarelerini yetkilendirmiştir (md. 1). Kanun kapsamında sit alanı olarak ilan edilen bölgeler ile bu bölgelere ait koruma alanları içerisindeki koruma amaçlı ve yeniden inşa amaçlı kentsel dönüşüm projeleri amaçlanmıştır.

Yenileme alanları; il özel idarelerinde il genel meclisinin ve belediyelerde belediye meclisinin üye tam sayısının salt çoğunluğunun kararı ile belirlenir. İl özel idaresinde il genel meclisince ve büyükşehirler dışındaki belediyelerde belediye meclisince bu konuda alınan kararlar, Cumhurbaşkanına sunulur. Büyükşehirlerde ise ilçe belediye meclislerince alınan kararlar, büyükşehir belediye medisince onaylanması üzerine Cumhurbaşkanına sunulur. Cumhurbaşkanı projenin uygulanıp uygulanmamasına üç ay içinde karar verir. Cumhurbaşkanınca kabul edilen alanlardaki uygulama bir program dahilinde etap etap projelendirilebilir. Etap proje ve programları, meclis üye tam sayısının salt çoğunluğunun kararı ve belediyelerde belediye başkanının, il özel idarelerinde valinin onayı ile uygulamaya konulur (md. 2). Yenileme alanlarındaki projeler yenileme projesi olarak tanımlanmaktadır. Büyükşehirlerde ilçe belediyelerinin hazırladıkları yenileme projeleri büyükşehir belediye başkanının onayıyla yürürlüğe girer.

Yenileme alanlarında TOKİ ile ortak uygulama yapılabileceği gibi, TOKİye de uygulama yaptırılabilir (md. 3).

Yenileme projeleri, uygulama alanı içerisinde bulunan taşınmaz kültür ve tabiat varlıklarının rölöve, restitüsyon, restorasyon projeleri ile onarılacak veya yeniden inşa edilecek yapıların imar mevzuatında öngörülen projelerinden oluşur (md. 3).

Yenileme alanlarında bulunan yapıların boşaltılması, yıkımı ve kamulaştırılmasında anlaşma yolu esastır. Anlaşma sağlanamayan hallerde gerçek ve özel hukuk tüzel kişilerinin mülkiyetinde bulunan taşınmazlar ilgili il özel idaresi ve belediye tarafından kamulaştırılabilir (md. 4).

Kanun açıklamaları göstermektedir ki, ilk defa kentsel dönüşüm tarihi kültürel değeri olan ve korunması kent için ve toplum için yararlı görülen 
alanların yenilenmesi konusunda yerel yönetimleri yetkilendirmiştir. Bir önceki özel düzenlemeden farklı olarak genel olarak yerel yönetimleri yetkilendiren bu kanun kentsel dönüşümü koruma amaçlı projeler ile sınırlandırmıştir.

\section{5 tarih ve 5393 sayılı Belediye Kanunu}

Üçüncü olarak, 2005 tarih ve 5393 sayılı Belediye Kanunu'nun Çeşitli ve Son Hükümler başlıklı Altıncı Kısımında "Kentsel Dönüşüm ve Gelişim Alanı" 73. madde altında düzenlenmiştir. Bu maddenin düzenlemelerinden bazıları 2010, 2012 ve 2014 yıllarında değiştirildiği gibi, 2012 yılında Anayasa Mahkemesi tarafından iptal edilen düzenlemeleri de olmuştur.

Belediye, belediye meclisi kararıly;

"konut alanları, sanayi alanları, ticaret alanları, teknoloji parkları, kamu hizmeti alanları, rekreasyon alanları ve her türlü sosyal donatı alanları oluşturmak, eskiyen kent kısımlarını yeniden inşa ve restore etmek, kentin tarihi ve kültürel dokusunu korumak veya deprem riskine karşı tedbirler almak amaciyla kentsel dönüşüm ve gelişim projeleri uygulayabilme"

konusunda yetkilendirilmiştir.

Bir alanın kentsel dönüşüm ve gelişim alanı olarak ilan edilebilmesi için yukarıda sayılan hususlardan birinin veya birkaçının gerçekleşmesi ve bu alanın belediye veya mücavir alan simırları içerisinde bulunması şarttır. Ancak, kamunun mülkiyetinde veya kullanımında olan yerlerde kentsel dönüşüm ve gelişim proje alanı ilan edilebilmesi ve uygulama yapılabilmesi için ilgili belediyenin talebi ve Cumhurbaşkanınca bu yönde karar alınması şarttır.

Kentsel dönüşüm ve gelişim proje alanı olarak ilan edilecek alanın büyüklüğünün "en az 5 en çok 500 hektar arasında" olması gerekmektedir. Toplamda 5 hektardan az olmayan proje alanı ile ilişkili birden fazla yer tek bir dönüşüm alanı olarak belirlenebilir.

Büyükşehir belediye ve mücavir alan sınırları içinde kentsel dönüşüm ve gelişim projesi alanı ilan etmeye büyükşehir belediyeleri yetkilidir. Büyükşehir belediye meclisince uygun görülmesi halinde ilçe belediyeleri kendi sinırlar içinde kentsel dönüşüm ve gelişim projeleri uygulayabilir.

Kentsel dönüşüm ve gelişim proje alanlarında bulunan yapıların boşaltılması, yıkımı ve kamulaştırılmasında anlaşma yolu esastır.

Kentsel dönüşüm ve gelişim proje alanlarında yapılacak alt yapı ve rekreasyon harcamaları, proje ortak gideri sayılır. Proje ortak gideri ödenmeden inşaat ruhsatı, yapılan binalara yapı kullanma izni verilemez; su, doğalgaz ve elektrik bağlanamaz. 
5393 sayılı Belediye Kanunu, kentsel dönüşüm ve gelişim alanı tanımı ile kentsel dönüşüm uygulamalarını sadece koruma altına alınmış alanların kapsamından çıkararak genişletmiş; geniş bir yorumla konut, sanayi, teknoloji, ticaret, kamu hizmeti, rekreasyonel ve sosyal donatı alanlarını kapsamı içine almıştır. Yine kentin tarihi ve kültürel dokusunu koruma amacını taşımakla birlikte, deprem riskine karşı önlemler almak ve kentin gelişimine katkı sunmak gibi amaçlarla ile kentsel dönüşüm politikasının amaçlarını büyütmüştür. Kentsel dönüşüm ve gelişim alanı ilan edilecek yerlerin ölçeği büyütülmüş ve en az 5 hektar ve en fazla 500 hektar gibi alt ve üst limit tanımlanmıştır. Bu alanları belirleme yetkisi esas olarak belediyelere bırakılmakla birlikte; kamu mülkiyeti ve kullanımı olan yerlerde Cumhurbaşkanının onayı gerekli tutulmuştur. Büyükşehir belediyelerinde ise büyükşehir belediyesi ilçe belediyesinin üzerinde bir vesayet makamı olarak tanımlanmıştır. Aslında burada merkezi yönetim-yerel yönetimler, büyükşehirler-ilçeler arasında bir plan bütünselliği amacı güdüldüğü de söylenebilir.

Proje alanlarında süreçlerin anlaşma yoluna bağlanması toplumun rızası ve desteği açısından önemli bir ilkedir.

\section{2 tarih ve 6306 sayılı Afet Riski Altındaki Alanlarnn Dönüş̧ürülmesi Hakkindaki Kanun}

Son olarak, 2012 yılında 6306 sayılı Afet Riski Altındaki Alanların Dönüştürülmesi Hakkında Kanun yürürlüğe girmiştir. Bu Kanun, kentsel dönüşüm alanını sınırlandırmış ve afet riskli alanları kapsamına almıştır. Kanun kapsamında belediyeler, büyükşehir belediyeleri, il özel idareleri, büyükşehirlerde Bakanlıkşa yetkili kılınması durumunda ilçe belediyeleri yetkili kılınabilir. Kanunda asıl yetkilerin Çevre ve Şehircilik Bakanlığı ve TOKİ'nin elinde toplandığı görülmektedir. Kentsel dönüşüm uygulamalarının merkezileşmesi tercihi politikada ve düzenlemelerde öne çıkmaktadır. Kısaca değerlendirilirse Bakanlık, her tür ve ölçekte plan yapma yetkisine sahip kılınmış ve belediyelerin üstünde onay makamı olarak tanımlanmıştır.

6306 Sayılı “Afet Riski Altındaki Alanların Dönüştürülmesi Hakkındaki Kanun", afet riski altındaki alanlar ile bu alanlar dışındaki riskli yapıların bulunduğu arsa ve arazilerde, fen ve sanat norm ve standartlarına uygun, sağlıklı ve güvenli yaşama çevrelerini teşkil etmek üzere iyileştirme, tasfiye ve yenilemelere dair usul ve esasları belirlemek üzere 2012 yılında düzenlenerek uygulamaya geçmiştir. Bu Kanunun uygulanmasında Bakanlık: Çevre ve Şehircilik Bakanlığını; İdare: Belediye ve mücavir alan sınırları içinde belediye- 
leri, bu sınırlar dışında il özel idarelerini, büyükşehirlerde büyükşehir belediyelerini ve Bakanlık tarafından yetkilendirilmesi halinde büyükşehir belediyesi sınırları içindeki ilçe belediyelerini; TOKİ: Toplu Konut İdaresi Başkanl1ğını ifade eder.

6306 sayılı Kanunun Uygulama Yönetmeliği'nde “ilgili Kurum” tanımlanmıştır. Buna göre, ilgili kurum uygulama alanında dönüşüm projesi gerçekleştirecek olan Bakanlığı, İdareyi ve Toplu Konut İdaresi Başkanlığını ifade eder.

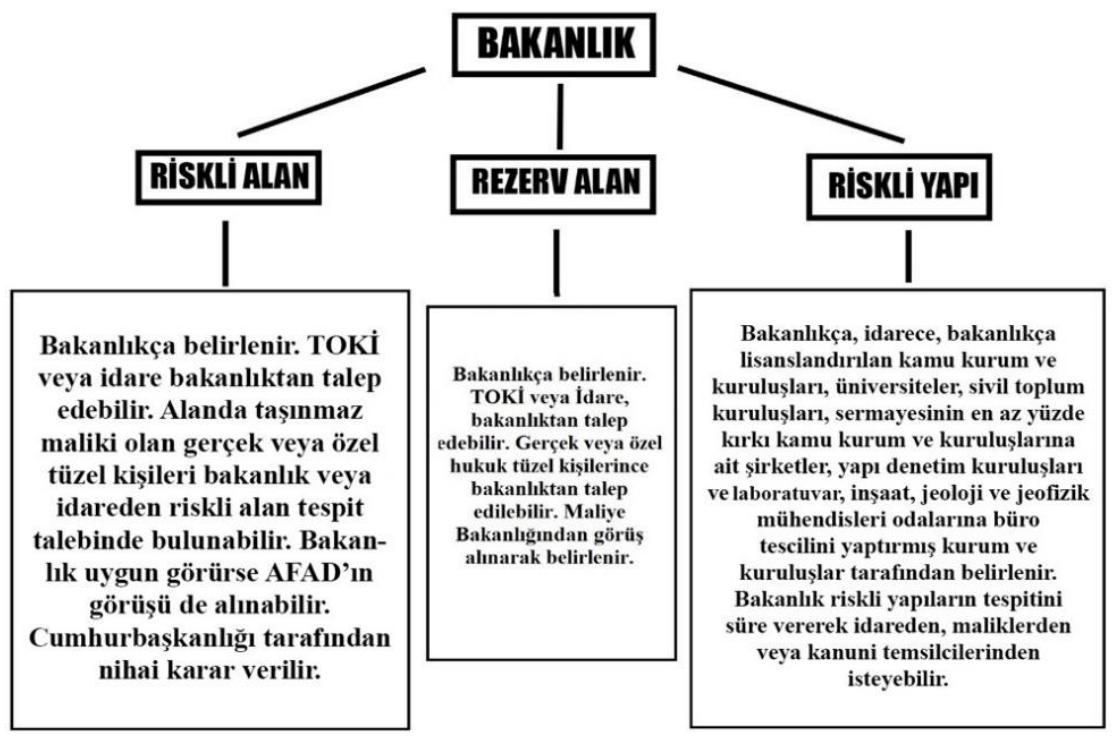

Şekil 1. 6306 sayılı Kanuna göre Kentsel Dönüşüm Aktörleri ve İşlemleri

Kanunun uygulanmasında Rezerv Yapı Alanı, Riskli Alan ve Riskli Yapı kavramları öne çıkmaktadır. Rezerv Yapı Alanı, bu Kanun uyarınca gerçekleştirilecek uygulamalarda yeni yerleşim alanı olarak kullanılmak üzere, TOKİnin veya İdarenin talebine bağlı olarak veya resen, Maliye Bakanlığı'nın uygun görüşü alınarak Bakanlıkça belirlenen alanları ifade etmektedir. Riskli Alan, "zemin yapısı veya üzerindeki yapılaşma sebebiyle can ve mal kaybına yol açma riski taşıyan", Cumhurbaşkanınca kararlaştırlan alanı ifade etmektedir. Riskli Yapı, "riskli alan içinde veya dışında olup ekonomik ömrünü tamamlamış olan ya da yıkılma veya ağır hasar görme riski taşıdığı ilmi ve teknik verilere dayanılarak tespit edilen yapıyı" ifade etmektedir. 6306 sayılı Kanunun Uygulama Yönetmeliği'ne göre Uygulama Alanı, Cumhurbaşkanınca 
kararlaştırılan riskli alan ile Bakanlıkça belirlenen rezerv yapı alanını ve riskli yapının veya yapıların bulunduğu alanı ifade etmektedir.

Bu tanımlara göre, riskli alan ve yapılarda yapılacak kentsel dönüşümün amacı afet riski taşıyan alanlardaki zemin yapısı veya buralardaki yapılaşmanın yol açacağı can ve mal kaybını önlemek; ekonomik ömrünü tamamlamış, yıkılma riskine sahip veya afet sonrası ağır hasar görebilecek yapıları temizlemek ve böylece planlı, afete dayanıklı, kaliteli yapı malzemesi ile inşa edilmiş, sağlıklı ve güvenli yaşama çevrelerini geliştirmektir.

Bir bölgenin kentsel dönüşüme dahil edilmesini gerektiren birden fazla sebep olduğu gibi, her bir sebebin ayrı dinamikleri olduğu da aşikârdır. Öncelikle, riskli alan olduğu için kentsel dönüşüm kapsamına alınan bir bölgede ilk yapılması gereken bölgenin risk haritasının çıkartılmasıdır. Riskli alanda kentsel dönüşüm yapılmasının sosyal ve ekonomik gerekçelerinin yanı sıra ve hatta onların da üzerinde olan neden, vatandaşların can ve mal güvenliğini tesis etme ve koruma zorunluluğudur. Bu sürecin somut bir biçime kavuşması kentsel dönüşümün sağlıklı işlemesi için gereklidir. Bu sebeple sorumlu İdare, vatandaşların can ve mal güvenliğini en ön plana alacak şekilde riskli alanların risk derecelerinin bulunduğu risk haritalarını hazırlamalı ve bu analizler sonucunda tehlikeli görünen bölgeleri riskli alan olarak ilan etme sürecine girmeli ve kentsel dönüşüm projeleriyle bu alanları can ve mal güvenliğini tehdit etmeyen alanlar haline getirmelidir.

Riskli alanın ilanı sürecinde yaşanan yönetsel sorunların çözümü, temelde herhangi bir ihtilafa ve şüpheye mahal vermeyecek şekilde alanın tespit ve ilanına dayanmaktadır. Kanuna göre, riskli alan ilan edilirken birinci amaç, afet riski olan yerlerde afete dayanıksız yapıların ve can ve mal kaybına yol açabilecek riskli yapılaşmaların önüne geçebilmektir. 6306 sayılı Kanun ve Uygulama Yönetmeliğinin çizdiği çerçeve bu türden olumsuzlukların önüne geçmek adına Cumhurbaşkanlığını ve Bakanlığı yetkilendirmiş ve sorumlu idarelerin izleyeceği yolu açık bir şekilde belirlemiştir:

Birinci olarak, alanın zemin yapısı veya üzerindeki yapılaşma sebebiyle can ve mal kaybına yol açma riski taşıdığına dair teknik raporu; Alanın büyüklüğünü de içeren koordinatlı sınırlandırma haritasını, varsa uygulama imar planını; Alanda bulunan kamuya ait taşınmazların listesini; Alanın uydu görüntüsünü veya ortofoto haritasın; Zemin yapısı sebebiyle riskli alan olarak tespit edilmek istenilmesi halinde yerbilimsel etüd raporunu; alanın özelliğine göre Bakanlıkça istenecek sair bilgi ve belgeleri ihtiva edecek şe- 
kilde hazırlanmış, olan dosya gereklidir. Buna bağlı olarak riskli alanın Kanun'da yapılan değişiklik ile Cumhurbaşkanınca kararlaştırılması yeterlidir (Yönetmelik, md.5/1).

İkinci olarak, Çevre ve Şehircilik Bakanlığı Kamu düzeni veya güvenliğinin olağan hayatı durduracak veya kesintiye uğratacak şekilde bozulduğu yerlerde (Planlama veya altyapı hizmetlerinin yetersiz olması, İmar mevzuatına aykııı yapılaşmanın bulunması, Altyapı veya üstyapıda hasar meydana gelmiş, olması sebeplerinden birinin veya bir kaçının bir arada bulunması halinde); üzerindeki toplam yapı sayısının en az \% 65'i imar mevzuatına aykırı olan veya yapı ruhsatı alınmaksızın inşa edilmiş, olmakla birlikte sonradan yap1 ve iskân ruhsatı alan yapılardan oluşan alanlarda uygulama bütünlüğü gözetilerek belirlenen alanlar, riskli alan olarak belirlenmek üzere teklif olarak Cumhurbaşkanlığı'na sunulabilir (Yönetmelik, md.5/2).

Üçüncü olarak, TOKİ veya İdare, riskli alan belirlenmesine ilişkin bilgi ve belgeleri ihtiva eden dosyaya istinaden Bakanlıktan riskli alan tespit talebinde bulunabilir. Bakanlıkça uygun görülen talepler Cumhurbaşkanlığı'na sunulur (Yönetmelik, md.5/3).

Dördüncü olarak, Riskli alan belirlenmesi için alanda taşınmaz maliki olan gerçek veya özel hukuk tüzel kişileri, riskli alan belirlenmesine ilişkin bilgi ve belgeleri ihtiva eden dosya ile birlikte Bakanlık veya İdareden riskli alan tespit talebinde bulunabilir. İdareye yapılacak talepler Bakanlığa iletilir. Bakanlıkça uygun görülen talepler Cumhurbaşkanlığı'na sunulur (Yönetmelik, md.5/4).

Mevcut duruma göre, bir alan zemin yapısı ve üzerindeki yapılaşma ile can ve mal güvenliğini tehdit ediyorsa; bir alanda kamu düzeni ve güvenliği olağanüstü düzeyde bozulmuşsa; bir alanın üzerindeki yapı stokunun çoğunluğu imar mevzuatına aykırı inşa edilmişse, bazı durumlarda doğrudan, bazı durumlarda ise TOKİ, İdare, gerçek veya özel hukuk tüzel kişilerinin başvurusu ve Bakanlığın dosyayı incelemesi-onayı ve sonra teklifi/iletmesi üzerine Cumhurbaşkanlığı tarafından riskli alan edilmesi karara bağlanacaktır. Cumhurbaşkanlığı teklifi onayladıktan sonra riskli alan ilanı Resmi Gazete' de yayımlanur.

Riskli alan başvurusundan önce, ilgili Kurumun jeolojik ve jeoteknik etütleri yaptırması gerekir. Bu etütlere dayalı olarak, zeminde "taşıma kapasitesi düşük, göçmelere sebep olabilir, bataklık, kum üzerinde vb." gibi sonuçlarla yapılaşma sıkıntısı olduğu kararı verilebilir. Bu aşamada riskli alanın zemin sorunu var ise, yerinde dönüşüm uygulaması tercih edilmeyebilir. Ancak, 
güçlü zemin iyileştirme maliyetlerine katlanılırsa yerinde dönüşüm yapılabilir.

6306 sayılı Kanun, doğayı, kültürel varlığı, kıyıları ve toprağı koruyan birçok kanunun dönüşüm sürecinde uygulanamayacağını düzenlemiştir. Ayrıca, kentsel dönüşüm İmar Kanunu'nun dışına çıkarılarak kent planlamasında ikili bir yapı geliştirilmiştir. Bunlara ek olarak, kentsel dönüşüme hiçbir şekilde halk katılımı öngörülmemiştir. Son olarak, dönüşüm uygulamalarına ilişkin kararlarda 'yürütmeyi durdurma kararı' verilemeyeceği kurala bağlanmıştır (Keleş, 2013, s.399-401). Kentsel dönüşüum projelerinde 'imar hakk1 toplulaştırılması' ya da 'imar hakkı aktarımı' gibi yöntemlerle kamu mülkiyetindeki toprağın paylaştırılması toplum ve gelecek kuşaklar için zararlı sonuçlar doğuracaktır (Keleş, 2013, s.401). Özellikle kamuoyunda artan talepler, uygulamada görülen sıkıntılar ve politika tercihlerindeki değişimler 'yerinde dönüşümü, hak sahipleri rızasını ve katılımını, işyerlerinin ekonomik durumunu, mahalle yaşantısını, sosyal donatıları ve kamusal hizmet alanlarının yeterliliğini' esas alan kentsel dönüşüm uygulamalarını gerektirmektedir. Böylece kentsel dönüşüm uygulamalarına toplumsal destek artacak ve girdi meşruiyeti sağlanacak; diğer yandan, proje sonrasında hak sahipleri ve diğer ilgililer yaşam çevrelerinde sürdürülebilir bir şekilde mahalle kültürlerini geliştirebilecek ve çktı meşruiyeti sağlanabilecektir.

\section{Tartışma ve Sonuç}

Yerel yönetimler klasik olarak kentlerdeki mahalli müşterek ihtiyaçları karşılamak üzere örgütlenmişlerdir. Her geçen gün insan kaynaklı ya da doğa kaynaklı yeni sorunlar yerel yönetimlerin sorumluluğunu artırmakta ve politikalarını çeşitlendirmektedir. Küresel ortamda ortaya çıkan hassasiyetler ya da politikalar da bu durumu güçlendirmektedir. İklim değişimi sorunu, yenilenebilir enerji ve ekolojik dengenin korunması ya da sürdürülmesi amacı yerel yönetimlerin göz ardı edemeyecekleri politikalar olmuştur (Beatley, 2012; Bulkeley ve Kern, 2006; Campbell ve Corley, 2012; Çoban, 2015). Kent merkezli çevreye verilen zararın artması, karbon salınımını azaltıcı palyatif tedbirler kentlerdeki yaşam kalitesini düşürücü bir boyuta ulaşmıştır. Özellikle sanayi yoğun, trafik yoğun ve kirlilik yoğun kent görüntüleri yaşam kalitesini sınılarken, yerel yönetişim aktörleri bu sorunların çözümüne yönelik ilgiyi artırabilmektedir. Dolayısıyla sivil toplumun artan gücü ve yerel yönetimlerle koordineli ve birlikte çalışmaları iklim değişimi ile mücadele ve 
yaşam kalitesini ilgilendiren önemli bir unsur dikkate alınmayı gerektirmektedir.

Yerel yönetimler, yerel yönetişim, yerellik bazında ortaya çıkan gelişmeler bir yönüyle ciddi bir yerelleşme reformunu ortaya çıarmışsa da, 2008 finansal krizinden sonra dünyada, Avrupa'da (Franzke, 2016) ve özellikle 2011 yılı sonrasında Türkiye'de merkezileşme yönünde gelişmelerin yaşandığı söylenebilir (Sadioğlu, 2018). Merkezileşmenin ekonomik, mali, siyasal, teknolojik ve kültürel birçok sebebi olabileceği gibi kent hizmetleri ve kentleşme politikaları üzerinde önemli sonuçları olmuştur. Bu bağlamda, bir yönüyle büyükşehir belediyeleri yerel ölçekte 'yerelde merkezileşme'nin özneleri olurken; diğer yönüyle Çevre ve Şehircilik Bakanlığı kent hizmetleri, kent planlaması ve kentsel dönüşüm başlıklarıyla ülke genelinde yerelle ilişkili merkezileşmenin aktörleri haline gelmişlerdir. Kentsel dönüşüm politikası hem belediyelerin hem de merkezi yönetimin sahiplendiği, merkezi yönetimin yönlendirdiği ve yerel yönetimlerin yürüttüğü bir politikaya dönüşmüştür (Sadioğlu ve Eseroğlu, 2017). Burada önemli olan ise kentsel dönüşümün plansız, çarpık, düzensiz ve alt yapısız kent sorunlarını çözmesi; kentteki sosyal, kültürel ve ekonomik grupların farklı alandaki sorunlarına çözümler getirmesi; özellikle sürdürülebilir kentleşmeye katkı sunması ve sosyal grupların ekonomik hayatını da canlandırması; barınma hakkının kullanılabilmesi ve yaygınlaştırılması için çözümler sunması ve genel olarak farklı sektörleri hareketlendirerek kent ekonomisi ve ülke ekonomisinde itici güç olmasıdır (Sadioğlu vd., 2016). Ancak, kentsel dönüşümün kamu yararı ya da kamu değeri kapsamında düşünülecek çıktılardan ziyade, özellikle sermayenin yeniden inşası, sosyal dışlama, mutenalaştırma (soylulaştırma) (bkz. Smith ve Williams, 2015), toplumsal kronik sorunları çözmektense derinleştirme gibi olumsuz çıktıları da görülmektedir (Bahçeci ve Görmez, 2018; Bayraktutan vd. 2016; Bıçkı, 2012; Erman, 1996, 1997; Tekeli, 2011).

Gecekondu ve kentsel çöküntü alanlarının barındırdığı sorunların çözümü kentlerdeki yaşam kalitesini artırmak için önemli bir politikadır. Kentsel dönüşüm bu bağlamda önemli bir araçtır; ancak kentsel dönüşümün yerel yönetişim aktörleriyle birlikte kurgulanması, plan ve projenin yine katılımcı bir şekilde ve ihtiyaçları önceleyen bir yaklaşımla ele alınması bunu sağlayabilir (Chan ve Lee, 2008). Sadece piyasa aktörleri ve süreçlerine bırakılmayan, kentteki tüm kesimleri kapsayan bir kentsel dönüşümün yaşam kalitesini belirleyen önemli bir değişken olduğu görülmektedir.

Türkiye'deki dönüşüm projelerinde, "kent adına söz söyleyebilecek STK'lar ve meslek kuruluşları sınırlı düzeyde yer almakta, ama sermaye ve 
girişimciler temel yetkili konumlarını sürdürmektedirler" (Keleş, 2013, s. 397). Kentsel dönüşüm sorunları sadece hukuk ya da kanun metinleriyle çözülebilecek bir sorun değildir. Sorunların ekonomik, sosyal ve ideolojik karşılıklarıyla, yine politikaların içeriğiyle birlikte ele alınması gerekir. Keleş'e (2013, s. 399) göre, kentsel dönüşüm projelerinde ideal yöntem kentsel toprak rantının paylaştırılması değil, tümüyle kamu mülkiyetine geçirerek sorunların uzun vadeli çözümlerle ele alınmasını sağlamaktır. Aslında ortaya çıkan mevzuat ve özellikle 6306 sayılı Kanunun çizdiği çerçeve, sunduğu imkân ve kolaylıklar, ilgili idareye sağladığı yetkiler, hak sahipleri ve kiracılar için getirdiği destekler yeterli görülmektedir. Önemli olan kamu yararı amacına yönelik, "sorumlu paydaş" bilinci ve yerel yönetişim anlayışıla kentsel dönüşümün planlanması, projelendirilmesi ve uygulanmasıdır. Özellikle uygulamaların izleme ve değerlendirilmesi bağımsız aktörlerce sağlanırsa kentsel dönüşüm "sosyo-mekânsal dönüşüme" katkı sunabilecektir. 


\title{
Extended Abstract
}

\section{Content, Actors and Aims of Urban Transformation in Turkey}

\author{
Uğur Sadioğlu \\ ORCID: 0000-0002-2454-4163
}

\author{
Eser Ergönül \\ ORCID: 0000-0002-3883-4129
}

Urban transformation includes a wide range of policy areas and various policy instruments. Urban transformation is a whole of strategies and actions implemented with approaches to improve the economic, social, physical and environmental conditions of urban space, which is collapse and deterioration, with comprehensive and integrated approaches. Urban renewal policies in recent years in Turkey is an important policy agenda. Many years of unhealthy urbanization accumulation, insufficient physical equipment due to experienced and probable disaster risks, increasing social, economic and cultural problems in cities in recent years, the destruction that emerged after terrorist attacks in cities and the strategy of building the cities of the future make urban reproduction of space. Turkey's economy and democratic political life, young and dynamic human capital, a large number of domestic and foreign new waves of migration faced by the different actors and factors makes it necessary to take into consideration in the process of urban transformation.

The social, political, cultural, economic and technological environment that exists in the country system requires a highly legitimate urban transformation policy based on a participatory approach and protecting the interests of all actors. Governance, sustainability and urban transformation in the realization of basic understanding of the consequences of urban transformation projects that will positively affect Turkey's social and political, will feed into the economic and cultural development. The actors and the factors in every province in Turkey varies and this is something that should happen. What is important here is that urban reproduction can contribute to a sustainable urbanization process and the affected masses, citizens and all local actors can belong to newly produced urban spaces. New urban spaces to be realized within this framework 
will provide safe, livable and loyalty environments for its users and users. Urban consciousness of the masses with high belonging to new urban spaces will also develop. The main principle for this is to ensure the participation of social, political, economic and cultural actors in the city in urban transformation policy determination, implementation and evaluation processes. For this, there is a need for tools that contribute to the inclusion of all actors and factors of urban transformation.

Urban buildings and spaces are transformed over time under the influence of physical, social, natural, environmental, economic, cultural and even political and ideological factors, and these areas and spaces can cause many transformations too. While the transformations in these spaces sometimes aim to increase the quality of space and life, sometimes it becomes an imperative due to the deterioration in terms of environmental, physical, social, economic etc. Disaster risks frequently encountered in some countries and spatial destructions caused by human in some countries direct urban and national administrations to urban transformation.

Urban transformation is, in general, the creation of a viable road map by examining the social, economic and spatial characteristics of an urban building or area, taking into account urban problems, needs, priorities and development aspects.

Major urban transformation projects aim to solve the causes of urban collapse and urban degradation and related problems and contribute to the development of the city by taking into account the factors such as socio-economic, physical, infrastructural, environmental etc. For these purposes, urban transformation aims to revitalize areas that have gradually lost their attraction, to increase the quality in physical and vital sense, a safer, healthier and prosperous urban life. It carries out the construction of the buildings in a way that prevents the re-emergence of situations such as unplanned and crooked construction. Controlling the scattered construction is another purpose.

With these features, urban transformation, due to its field of activity and nature, can affect the physical structure of the existing city and the social and economic future of the people living there and consequently all the traditions of the city.

In urban transformation projects, one or more of these goals may come to the fore, depending on the nature and potential of the region the ultimate aim of urban transformation is to create cities with livable standards for people. Practices should therefore also be built mainly on social foundations. 
Urban transformation in Turkey, especially from the 1980s come to the fore from time to time by the central government but also local governments are walking in a medium that becomes a major practitioners in private sector cooperation. A complex image is encountered in urban transformation practices, which are the area of authority, duty and responsibility of both central government and local governments.

The primary reason that the central government assumes both decision-making, implementing and supervisory roles in the implementation of urban transformation projects is that it can be more effective in the realization of projects with its economic power and legal authority.

On the other hand, considering local governments as local actors, they play a very important role as organizations that directly interact with the beneficiaries who will be affected by the projects they carry out and who know the needs of the region best. Municipalities play a priority role in terms of participation and governance so that the output of the project is positive in the long term and that the work will be owned by the citizens.

In the study, the legislation regulating this multi-actor and complex structure of urban transformation was examined in terms of its aims and meaning. Thus, it is aimed to evaluate the urban transformation practices that have gained a negative image in recent years, in a healthy way. Finally, by analyzing the institutional framework it was reviewed in Turkey.

\section{Kaynakça/References}

Afet Riski Altındaki Alanların Dönüştürülmesi Hakkındaki Kanun (2012, 31 Mayıs). Resmî Gazete (Sayl: 28309). https://www.mevzuat.gov.tr/mevzuat?MevzuatNo=6306\&MevzuatTur=1\&MevzuatTertip=5 adresinden erişilmiştir.

Akkar, Z. M. (2006). Kentsel dönüşüm üzerine batı'daki kavramlar, tanımlar, süreçler ve Türkiye. Planlama, 2, 29-38.

Akkoyunlu Ertan, K. (2014). Kent ve kentli hakları. Ankara: Türkiye ve Orta Doğu Amme İdaresi.

Ataöv, A. ve Sevin O. (2007). Türkiye'de kentsel dönüşüme yöntemsel bir yaklaşım. METU JFA, 24 (2), 57-82.

Bahçeci, H. I. ve Görmez, K. (2018). Türkiye'nin kentsel dönüşüm pratiği. A. Mengi ve D. İşçioğlu (Der.), Kentsel Politikalar içinde (s. 105-122). Ankara: Palme Yayıncilı.

Bayraktutan, Y., Akbulut, F. ve Özbilgin, M. (2016). Mekânsal ayrışma: iktisadi dinamikleri ve Türkiye üzerine bir değerlendirme. Journal of International Social Research, 9(43), 1669-1682. doi: 10.17719/jisr.20164317737 
Beatley, T. (Der.). (2012). Green cities of Europe - global lessons on green urbanism. Washington: Island Press.

Belediye Kanunu (2005, 13 Temmuz). Resmî Gazete (Sayı: 25874). https://www.mevzuat.gov.tr/mevzuat?MevzuatNo=5393\&MevzuatTur=1\&MevzuatTertip=5 adresinden erişilmiştir.

Berg, L. van den, J. van der Meer ve P. M. J. Pol (2003). Organising capacity and social policies in European cities. Urban Studies, 40(10), 1959-1978. doi: 10.1080/0042098032000116068

Bıçk1, D. (2012). Küreselleşme sürecinde kentler: mekansal yarılma, yoksulluk ve Türkiye. M. Zencirkıran (Der.), Dünden bugüne Türkiye'nin toplumsal yapısı içinde (s. 361383). Bursa: Dora Yayınclik.

Bulkeley, H. ve Kern, K. (2006). Local government and the governing of climate change in Germany and the UK. Urban Studies, 43(12), 2237-2259. doi: $10.1080=00420980600936491$

Campbell, H. E. ve Corley, E. (2012). Urban environmental policy analysis. New York: M.E. Sharpe.

Campbell, H., M. Tait ve C. Watkins (2014). Is there space for better planning in a neoliberal world? implications for planning practice and theory. Journal of Planning Education and Research, 34 (1), 45-59. https://doi.org/10.1177/0739456X13514614

Chan, E., ve Lee, G. K. L. (2008). Critical factors for improving social sustainability of urban renewal projects. Social Indicators Research, 85(2), 243-256. https://doi.org/10.1007/s11205-007-9089-3

Çoban, A. (2015). Yerel yönetim, kent ve ekoloji. Ankara: İmge Kitabevi.

Curry, N. (2012). Sustainable rural development in England: policy problems and equity $\begin{array}{llll}\text { consequences. } & \text { Local } & \text { Economy, }\end{array}$ https://doi.org/10.1177/0269094211428864

Dawe, N. K. ve K. L. Ryan (2003). The faulty three-legged stool model of sustainable development. Conservation Biology, 17(5), 1458-1460.

Demirkol, S. ve Bereket, B. (2013). Kentsel dönüşümün, 6306 sayılı yasa kapsamında hak ve özgürlükler açısından ele alınması. TBB Dergisi, 108, 23-70. https://jurix.com.tr/article/11124 adresinden erişilmiştir.

Erman, T. (1996). Women and the housing environment: the experiences of Turkish migrant women in squatter (Gecekondu) and apartment housing. Environment and Behavior, 28(6), 764-798. doi: https://doi.org/10.1177/001391659602800603

Erman, T. (1997). Squatter (gecekondu) housing versus apartment housing: Turkish rural-to-urban migrant residents' perspectives. Habitat International, 21(1), 91-106. https://doi.org/10.1016/S0197-3975(96)00048-3

Franzke, J. (2016). Structure of the local tiers in Germany: trends and challenges in local governance and autonomy. U. Sadioglu ve K. Dede (Der.), Comparative studies and regionally-focused cases examining local governments içinde (s.51-70). Hershey, Pennsylvania: IGI Global Publishing. 
Holden, M. (2012). Urban policy engagement with social sustainability in metro Vancouver, Urban Studies, 49 (3), 527-542. doi: https://doi.org/10.1177/0042098011403015

Keleş, R. (1998). Kentbilim terimleri sözlüğ̈̈ (2. bs.). Ankara: İmge Kitabevi.

Keleş, R. (2013). Kentleşme politikası. Ankara: İmge Kitabevi.

Kuzey Ankara Girişi Kentsel Dönüşüm Projesi Kanunu (2004, 12 Mart). Resmî Gazete (Sayı: 25400). https://www.mevzuat.gov.tr/mevzuat?MevzuatNo=5104\&MevzuatTur=1\&MevzuatTertip $=5$ adresinden erişilmiştir.

Lenger, F. (2012). European cities in the modern era, 1850-1914. Leiden: Global Oriental, Hotei Publishing.

McDonald, R. C. (2012). Sustainable buildings: a necessary component of sustainable communities. A. Dale, W. T. Dushenko and P. Robinson (Der.), Urban sustainabilityreconnecting space and place içinde (s.239-267). Toronto: University of Toronto Press.

OECD (Organisation for Economic Co-operation and Development) (2001). Analytic Report on Sustainable Development, SG/SD(2001)1-14, Paris: OECD.

Park, R. E. ve Burgess E. W. (Der.). (2016). Şehir kent ortamındaki insan davranışlarının araştırılması üzerine öneriler (P. Karababa-Kayalıgil, Çev.). Ankara: Heretik. (Orijinal eserin yayın tarihi 1925).

Peng, Y., Lai, Y., Li, X. ve Zhang, X. (2015). An alternative model for measuring the sustainability of urban regeneration: the way foeward. Journal of Cleaner Production, 109, 76-83. doi: https://doi.org/10.1016/j.jclepro.2015.06.143

Portney, K. E. (2003). Taking sustainable cities seriously: Economic development, the environment, and quality of life in American cities. Cambridge, MA: MIT Press.

Rapoport, A. (1983). Environmental quality, metropolitan areas and traditional settlements, HABITAT INTL., 7(3/4), 37-63. doi: https://doi.org/10.1016/01973975(83)90033-4

Sadioğlu, U. (2018). Türkiye ve Almanya'da yaşanan yerel yönetimler reformunun karşılaştırılması: Yeni bir model önerisi. Ankara: Seçkin Yayıncılık.

Sadioğlu, U. ve Eseroğlu, İ. (2017). Kentsel dönüşümde kültürel birikimin sürekliliği, kimliğin muhafazası ve aidiyetin geliştirilmesi: Konya-Bedesten örneği. U. Ömürgönülşen, M. K. Öktem ve U. Sadioğlu (Der.), Sürdürülebilir kent ve çevre yönetimi üzerine yazllar I içinde (s. 223-247). Ankara: Hacettepe Üniversitesi Yayınları.

Sadioğlu, U., Tiryaki, V. ve A. Korkmaz (2016). Altındağ belediyesi örneği üzerinden Türkiye'de kentsel dönüşüm politikasının değerlendirilmesi. Ankara Üniversitesi SBF Dergisi, 71(3), 757-796. doi: https://doi.org/10.1501/SBFder_0000002411

Salet, W. ve A. Thornley (2007). Institutional influences on the integration of multilevel governance and spatial policy in European city-regions. Journal of Planning Education and Research, 27, 188-198. doi: https://doi.org/10.1177/0739456X07307207

Scott, A. J. (2008). Inside the city: On urbanisation, public policy and planning. Urban Studies, 45 (4), 755-772. doi: https://doi.org/10.1177/0042098007088466

Smith, N. ve Williams, P. (Der.). (2015). Kentin Mutenalaştırılması. (M. Uzun, Çev.). İstanbul: Yordam Kitap. (Orijinal eserin yayın tarihi 2007). 
Tekeli, İ. (2011). Kent, kentli haklar, kentleşme ve kentsel dönüşüm yazıları. İstanbul: Tarih Vakfi Yurt Yayınları.

TÜBA (2016). Kentsel dönüşüm. Türkçe bilim terimleri sözlüğü. 23 Ocak 2020 tarihinde www.tubaterim.gov.tr adresinden erişildi.

Wassenberg, F. (2013). Large Housing estates: ideas, rise and recovery - The Bijlmermeer and beyond, Amsterdam: Delft University Press.

Weber, R. (2002). Extracting value from the city: neoliberalism and urban redevelopment. Antipode, 34 (3), 519-540. doi: https://doi.org/10.1111/1467-8330.00253

Yıpranan Tarihi ve Kültürel Taşınmaz Varlıkların Yenilenerek Korunması ve Yaşatılarak Kullanılması Hakkında Kanun (2005, 5 Temmuz). Resmî Gazete (Sayı: 25866). Erişim adresi: https://www.mevzuat.gov.tr/mevzuat?MevzuatNo=5366\&MevzuatTur=1\&MevzuatTertip $=5$.

Yırtıcı, Hakkı (2011). Türkiye' de bir sermaye birikim aracı olarak toprak rantı ve kent mekânının dönüşümü. Mimarlı Dergisi, 362, 62-65. http://www.mimarlikdergisi.com/index.cfm?sayfa=mimarlik\&DergiSayi=376\&RecID=2802 adresinden erişilmiştir.

6306 Sayılı Kanun'un Uygulama Yönetmeliği (2012, 15 Aralı). Resmî Gazete (Sayı: 28498). https://www.mevzuat.gov.tr/mevzuat?MevzuatNo=16849\&MevzuatTur=7\&MevzuatTertip=5 adresinden erişilmiştir. 